\title{
Knowledge, attitude and practice of contraception among paramedical staff at tertiary care centre
}

\author{
Indira Lamba, Manish Kumar Bhardwaj*
}

Department of Obstetrics and Gynaecology, SMS Medical College, Jaipur, Rajasthan, India

Received: 19 February 2021

Accepted: 01 April 2021

\section{*Correspondence:}

Dr. Manish Kumar Bhardwaj,

E-mail: manish_bhardwaj84@yahoo.com

Copyright: (c) the author(s), publisher and licensee Medip Academy. This is an open-access article distributed under the terms of the Creative Commons Attribution Non-Commercial License, which permits unrestricted non-commercial use, distribution, and reproduction in any medium, provided the original work is properly cited.

\begin{abstract}
Background: To assess the knowledge, attitude and practice of contraception among female paramedical staff, who is already working in the tertiary care hospital and identify the factors that hinders the use of contraception.

Methods: This cross-sectional study was done in the Dept. of obstetrics and gynecology, SMS Medical College and attached group of hospitals, Jaipur. The study group included 90 paramedical female staff of reproductive age group (20-45 years) working in this hospital. Their knowledge, attitude and practice on contraceptives were evaluated with the help of a predesigned questionnaire.

Results: It was found that $93 \%$ of female paramedical staff were using contraceptive method, most of them (70\%) using condom (barrier method) as contraceptive. since they were health worker about $88 \%$ has Contraceptive Information and $63 \%$ also has knowledge about post-partum lactational amenorrhea. $58 \%$ using contraceptive to Preventing unwanted pregnancy. $39 \%$ staff discontinued methods due to abnormal uterine bleeding and $20 \%$ not adopted any method due to fear of its side effect.

Conclusions: Although the level of knowledge, attitude and acceptance of contraception among female paramedical staff were very good but every health worker should teach the community on family planning holistically to increase the awareness so that family planning utilization will be enhanced. This study highlights that knowledge and awareness doesn't always lead to the use of contraceptives. There is still a need to educate and motivate.
\end{abstract}

Keywords: Knowledge, Attitude, Practice, Paramedical staff, Contraception

\section{INTRODUCTION}

The World Health Organization (WHO) defined family planning as giving chance to society to determine the number of children and pregnancy spacing through contraceptive method. ${ }^{1}$ Contraception in the simplest terms is the prevention of pregnancy and contraceptive methods, by definition, are the preventive methods to help women avoid unwanted pregnancies. ${ }^{2}$ Each year, about 79 million unintended pregnancies occur worldwide is well established fact that paramedical staff play important role in creating awareness and subsequently acceptance of contraceptives. $^{3}$
Use of contraceptives can prevent at least $25 \%$ of all maternal deaths by allowing women to prevent unintended pregnancies and unsafe abortions, and protect themselves from sexually transmitting diseases including HIV. One fifth of the maternal death in the world occur in India, which is estimated as 130 per 100,000 live births, and about $15 \%$ of the maternal deaths are due to unsafe abortions. $^{4}$

The aim of this study was to assess the knowledge, attitude and practice of contraception among paramedical staff and Identify factors that hinders the use of contraception. 


\section{METHODS}

This cross-sectional study was done in the Dept. of obstetrics and gynecology, SMS Medical College and attatched group of hospitals, Jaipur. The study group included 90 female paramedical staff of reproductive age group (20-45 years) working in this hospital. Study period of this study was February to July 2020.

\section{Inclusion criteria}

Female paramedical staff. Age 20-45 years who were willing to participate in our study.

\section{Exclusion criteria}

Paramedical staff age $>45$ years.

A well-structured questionnaire was used for data collection on general information, knowledge, attitude and practice regarding family planning methods, and contraceptive.

Descriptive statistics was used for data analysis. All the collected data were analyzed with regard to the information given by the paramedical staff in the set questionnaire.

\section{RESULTS}

Among the 90 female paramedical staff in the study group more than $80 \%$ were in the age group of 25 to 34 . Majority were Hindus (75.5\%) followed by others religion (13.3\%). Majority female paramedical staff were primi gravidas $(57.8 \%)$.

Table 1: Sociodemographic correlates.

\begin{tabular}{|llll|}
\hline $\begin{array}{l}\text { Characteris } \\
\text { tics }\end{array}$ & Category & Number & Percentage \\
\hline Age (years) & $20-24$ & 03 & $3.3 \%$ \\
\hline & $25-34$ & 72 & $80 \%$ \\
\hline & $35-45$ & 06 & $6.7 \%$ \\
\hline Religion & Hindu & 68 & $75.5 \%$ \\
\hline & Muslim & 10 & $11.1 \%$ \\
\hline \multirow{2}{*}{$\begin{array}{l}\text { Active } \\
\text { married life }\end{array}$} & Others & 12 & $13.3 \%$ \\
\hline & < years & 38 & $42.2 \%$ \\
\hline Parity & $>5$ years & 52 & $57.8 \%$ \\
\hline & P 1 & 52 & $57.8 \%$ \\
\hline & P2 and & 38 & $42.2 \%$ \\
\hline
\end{tabular}

\section{Knowledge}

Almost all of them had heard about family planning and aware of contraceptive. Almost all $(95.5 \%)$ of them had knew about barrier methods. about $80 \%$ were aware about sterilization and oral contraceptive pills, and over half $(53.3 \%)$ of them had heard about injectable contraceptives (Table 2).

Table 2: Knowledge about method of contraception $(\mathbf{n}=90)$.

\begin{tabular}{|lll|}
\hline Barrier method & 86 & $95.5 \%$ \\
\hline $\begin{array}{l}\text { IUCD (intra uterine } \\
\text { contraceptive devices) }\end{array}$ & 78 & $86.6 \%$ \\
\hline Sterilization & 72 & $80 \%$ \\
\hline Pills & 72 & $80 \%$ \\
\hline $\begin{array}{l}\text { Lactational } \\
\text { amenorrhea }\end{array}$ & 63 & $70 \%$ \\
\hline $\begin{array}{l}\text { Injectable } \\
\text { contraceptives }\end{array}$ & 48 & $53.3 \%$ \\
\hline
\end{tabular}

Table 3: Knowledge about source of contraceptive information.

\begin{tabular}{|lll|}
\hline & Number & Percentage \\
\hline Health professional & 79 & $87.7 \%$ \\
\hline Friends & 68 & $75.5 \%$ \\
\hline $\begin{array}{l}\text { TV /NEWS PAPER / } \\
\text { RADIO }\end{array}$ & 47 & $52.2 \%$ \\
\hline Family & 36 & $40 \%$ \\
\hline Social media & 34 & $30.6 \%$ \\
\hline
\end{tabular}

Table 4: Knowledge about method of post-partum contraception.

\begin{tabular}{|c|c|c|}
\hline & Number & Percentage \\
\hline $\begin{array}{l}\text { lactational } \\
\text { amenorrhea }\end{array}$ & 70 & $63 \%$ \\
\hline IUCD & 52 & $57.7 \%$ \\
\hline Sterilization & 38 & $42.2 \%$ \\
\hline Natural methods & 28 & $31.1 \%$ \\
\hline $\begin{array}{l}\text { PO pills (progesterone } \\
\text { only pills) }\end{array}$ & 10 & $11.11 \%$ \\
\hline $\begin{array}{l}\text { Injectable } \\
\text { contraceptives }\end{array}$ & 4 & $04.4 \%$ \\
\hline
\end{tabular}

Since they were health worker about $88 \%$ has Contraceptive Information and about $75 \%$ of staff got information about contraceptives form friends (Table 3)

About (63\%) female paramedical staff had knew postpartum lactational amenorrhea and few (4.4\%) of them were knew about postpartum injectable contraceptives (Table 4).

\section{Attitude}

All staff were willing to adopt family planning in future to delay or spacing the pregnancy and they would like to motivate their friends and relatives to use family planning (Table 5). 
Table 5: Attitude towards contraception.

\begin{tabular}{|lll|}
\hline & Yes & No \\
\hline $\begin{array}{l}\text { To delay or spacing the } \\
\text { pregnancy }\end{array}$ & $100 \%$ & $0 \%$ \\
\hline Accessibility & $100 \%$ & $0 \%$ \\
\hline Post-partum contraception & $100 \%$ & $0 \%$ \\
\hline Motivation to others & $100 \%$ & $0 \%$ \\
\hline
\end{tabular}

\section{Practice}

About $90 \%$ of female paramedical staff were using contraceptive method, most of them (70\%) using condom (barrier method) as contraceptive. Few (2.4\%) of them were also used natural method of contraception (Table 6).

Table 6: Practice of contraception.

\begin{tabular}{|c|c|c|}
\hline & $\begin{array}{l}\text { Number } \\
(\mathrm{n}=\mathbf{8 1})\end{array}$ & Percentage \\
\hline $\begin{array}{l}\text { Barrier method } \\
\text { (condom) }\end{array}$ & 57 & $70.3 \%$ \\
\hline IUCD & 10 & $12.2 \%$ \\
\hline OC pills & 05 & $06.2 \%$ \\
\hline Sterilization & 04 & $04.9 \%$ \\
\hline Injectable contraceptives & 03 & $03.7 \%$ \\
\hline Natural method & 02 & $02.4 \%$ \\
\hline
\end{tabular}

Table 7: Reason for using contraception.

\begin{tabular}{|lll|}
\hline $\begin{array}{l}\text { Preventing unwanted } \\
\text { pregnancy }\end{array}$ & 52 & $57.7 \%$ \\
\hline $\begin{array}{l}\text { Spacing of birth } \\
\text { Completed their families }\end{array}$ & 48 & $53.3 \%$ \\
\hline $\begin{array}{l}\text { Want to improve their } \\
\text { own and child health }\end{array}$ & 36 & $44.4 \%$ \\
\hline Prevents STDs & 28 & $40 \%$ \\
\hline Socio-economic & 17 & $31.1 \%$ \\
\hline
\end{tabular}

A total $57.7 \%$ female paramedical staff were using contraception to Preventing unwanted pregnancy and 53.3 for spacing of birth (Table 7).

Table 8: Reason for discontinuation of contraception.

\begin{tabular}{|lll|}
\hline $\begin{array}{l}\text { Irregular menstrual } \\
\text { bleeding }\end{array}$ & 35 & $38.8 \%$ \\
\hline Abdominal pain & 14 & $15.5 \%$ \\
\hline Back pain & 12 & $13.3 \%$ \\
\hline Desire to have child & 09 & $10 \%$ \\
\hline $\begin{array}{l}\text { Spontaneous expulsion } \\
\text { (IUCD) }\end{array}$ & 05 & $05.5 \%$ \\
\hline Failure & 04 & $04.4 \%$ \\
\hline
\end{tabular}

A total $38.8 \%$ staff discontinued the use of contraception due to Irregular menstrual bleeding and $15.5 \%$ due to abdominal pain. About 5.5\% staff also experienced spontaneous expulsion of IUCD (Table 8).

Table 9: Reason for not willing of contraception $(n=51)$.

\begin{tabular}{|c|c|c|}
\hline & Number & Percentage \\
\hline Fear of side effects & 18 & $20 \%$ \\
\hline Desire to have child & 09 & $10 \%$ \\
\hline $\begin{array}{l}\text { Already use natural } \\
\text { method }\end{array}$ & 06 & $06.6 \%$ \\
\hline $\begin{array}{l}\text { Opposition of } \\
\text { friends/family/husband }\end{array}$ & 05 & $05.5 \%$ \\
\hline Husband work far away & 05 & $05.5 \%$ \\
\hline Ignorance & 03 & $03.3 \%$ \\
\hline $\begin{array}{l}\text { Husband has used } \\
\text { contraception }\end{array}$ & 03 & $03.3 \%$ \\
\hline $\begin{array}{l}\text { Lack of information } \\
\text { about contraception }\end{array}$ & 02 & $02.2 \%$ \\
\hline
\end{tabular}

A total $20 \%$ female paramedical staff had the fear of side effect and $10 \%$ desire to have child, as a reason for not using contraception. There were (about 5.5\%) still had opposition from friends/relatives (Table 9).

\section{DISCUSSION}

Increasing program coverage and access of family planning will not be enough; providers should consider that their young patients may want to better understand benefits and side effects of their birth control outside of pregnancy prevention. Furthermore, young women may utilize their friends and family to make their contraceptive choice, which should be taken into consideration when counseling patients. ${ }^{5}$

In the present study more than $80 \%$ were in the age group of 25 and 34 years. The age group characteristics were similar to the study conducted by Renjhen Prachi et al in Sikkim, India. ${ }^{6}$ Mohanan et al in a study from Dakshina Kannada concluded that majority $(52.4 \%)$ of the women using contraception were in the age group of 15-34 years. ${ }^{7}$

In present study, $90 \%$ of female paramedical staff were using contraceptive method, most of them (70\%) using condom (barrier method) as contraceptive. Condom was the most common practiced method in this study followed by OCPs. Similar result was shown in other study as well. ${ }^{8-}$ ${ }^{10}$ In contrast, study conducted by Skogsdal et al The most commonly used contraceptive method was combined oral contraceptives, followed by long-acting reversible contraception. $^{11}$

In present study, result showed $63 \%$ female paramedical staff had knew about postpartum lactational amenorrhea and postpartum pregnancy similar results were seen in study conducted by Singh et al. ${ }^{12}$ Singh et al, mentioned that $60 \%$ women had awareness about postpartum high fertility rate. 
In present study results showed $20 \%$ female paramedical staff had the fear of side effect and $10 \%$ desire to have child as a reason for not using contraception in contrast, study conducted by Sato et al where the most common reason being side effects $(11.7 \%) .{ }^{13} 59.8 \%$ of women who discontinued did not switch to another method within 3 months following discontinuation and $20.9 \%$ experienced pregnancy.

\section{CONCLUSION}

Although the level of knowledge, attitude and acceptance of contraception among female paramedical staff were very good but every health worker should teach the community on family planning holistically to increase the awareness so that family planning utilization will be enhanced. This study highlights that knowledge and awareness doesn't always lead to the use of contraceptives. There is still a need to educate and motivate.

Funding: No funding sources

Conflict of interest: None declared

Ethical approval: The study was approved by the Institutional Ethics Committee

\section{REFERENCES}

1. Santoso BI, Surya R. Knowledge, Attitude, and Practice of Contraception among Pregnant Women in Ende District, East Nusa Tenggara, Indonesia. J South Asian Feder Obs Gynae. 2017;9(2):110-118.

2. Park K. Park's Textbook of Preventive and Social Medicine. 17th ed. Jabalpur: Banarasidas Bhanot. 2002:325-358.

3. Chavan GM. A Study of Knowledge, Attitudes and Practices Regarding Contraceptive Services Among Health Workers in Sangli District of Maharashtra, India. Natl J Community Med. 2014;5(4):414-8.

4. Zangmu Sherpa SZ. Journal of Family and Reproductive Health. 2013;7(3):115-120.

5. Hirth JM, Dinehart EE, Lin YL, Kuo YF, Patel PR. Reasons Why Young Women in the United States
Choose Their Contraceptive Method. J Womens Health (Larchmt). 2021;30(1):64-72.

6. Prachi R, Shuva G, Das, Ankur B, Jaju S, Khati B. A study of knowledge, attitude and practice of family planning among the women of reproductive age group in Sikkim. J ObstetGynecol India. 2007;58.

7. Donati S, Sharma N, Medda M. Family planning knowledge attitude and practice survey in Manipure state. J Obstet Gynecol India. 2003;53:485-90.

8. Khawaja NP, Tayyab R, Malik N. Awareness and practices of contraception among Pakistani women attending a tertiary care hospital. J Obstet Gynaecol. 2004;24:564-7.

9. Oyedeji OA, Cassimjee R. A gendered study of young adult contraceptive use at one university in Kwa ZuluNatal. Curationis. 2006;29(3):7-14.

10. Brahmbhatt MM, Sheth JK, Balaramanamma DV. A study of knowledge, attitude and practice towards contraception among married women of reproductive age group having $\leq 2$ children residing in Vasna ward, Ahmedabad, Gujarat, India. Healthline. 2013;4(2):812.

11. Skogsdal Y, Fadl H, Cao Y, Karlsson J, Tydén T. An intervention in contraceptive counseling increased the knowledge about fertility and awareness of preconception health-a randomized controlled trial. Ups J Med Sci. 2019;124(3):203-212.

12. Singh A, Meena P, Radhakrishnan G, Rutela M. A knowledge, attitude and practice study on awareness and acceptance of contraception in postpartum women in a tertiary care hospital. Int $\mathbf{J}$ Reprod Contracept Obstet Gynecol. 2016;5:1921-4.

13. Sato R, Elewonibi B, Msuya S, Manongi R, Canning $\mathrm{D}$, Shah I. Why do women discontinue contraception and what are the post-discontinuation outcomes? Evidence from the Arusha Region, Tanzania. Sexual and Reproductive Health Matters. 2020;28:1.

Cite this article as: Lamba I, Bhardwaj MK.

Knowledge, attitude and practice of contraception among paramedical staff at tertiary care centre. Int J Reprod Contracept Obstet Gynecol 2021;10:1931-4. 